\title{
Displacement and social assistance
}

\author{
Michael Collyer, Tahir Zaman, Dolf te Lintelo
}

\author{
February 2022
}

\section{Theme summary}

Displacement forms part of virtually any major crisis. It introduces a level of complexity when providing social assistance that leads to a specific, usually context-dependent set of challenges.

It is widely recognised that the vast majority of displaced people will travel as short a distance as possible to reach safety, whether as Internally Displaced Persons (IDPs), refugees or irregular migrants in neighbouring countries. Displaced people are disproportionately hosted in low- and middle-income countries, and the length of their displacement is increasing. This highlights the urgent priority of displacement; indeed, it has received sustained attention from the highest levels of global decision-making, particularly since 2016, including two Global Compacts in 2018 (Global Compact for Migration, Global Compact for Safe, Orderly and Regular Migration).
Although some have argued that such global summits offer a replacement for meaningful action, these events at least highlight clear political will to shift the emphasis from humanitarian responses to a much longer-term development focus. Interest in social assistance and displacement has also grown since 2018 and resulting policy must respond to this concern for more sustainable responses. High-level commitments are slowly filtering through to policy, while recent research has provided clear frameworks for analysing developing policy approaches. Gaps remain in the analysis of policy implementation and in the assessment of how to access social assistance beyond official state channels.

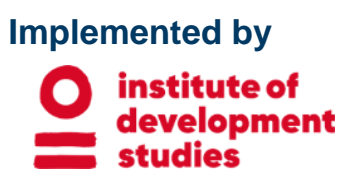

Better Assistance in Crises (BASIC) Research (funded by UKAid) aims to inform policy and programming on how to help poor and vulnerable people cope better with crises and meet their basic needs through more effective social assistance. All costs related to BASIC Research are covered by the UK Foreign, Commonwealth and Development Office. 


\section{State of the evidence and debate}

The relationship between displacement and social assistance received relatively little attention in the 2018 Global Compacts, but since then interest in the provision of social assistance for displaced people has grown considerably. Examples of cash assistance to displaced people go back more than a decade and other forms of assistance much longer than that. Yet, substantial, comparative research into these issues and resulting policy attention were not widespread before 2018 , so evidence in this area has a fairly recent history.

- Focus on national mainstreaming of social assistance. There is wide acceptance that the most sustainable forms of assistance are those delivered through national mechanisms. Separate systems operating parallel approaches for target groups such as displaced people are less desirable than 'piggybacking' onto existing policies or fully integrating with government systems.

- Different categories of displaced groups have distinct experiences but often overlapping vulnerabilities. Although refugees are a distinct group, as non-citizens their situation often overlaps with IDPs (internally displaced people), since IDPs are frequently denied assistance or are afraid to register. In some cases, non-displaced citizens may experience similar forms of marginalisation and may not be eligible for international support that is provided for refugees.

- Broad agreement exists that self-reliance is the primary goal for displaced people. The aim to foster self-reliance among displaced people is very widespread in international approaches. It reflects a range of policies from those supporting genuine autonomy to those keen to withdraw assistance as early as possible. More critical analysis of context-dependent meanings of self-reliance is required.

Table 1: The relationship between different categories of displacement and policy

\begin{tabular}{|c|c|c|c|}
\hline Displacement category & Discourse & Policy & Implementation \\
\hline Non-displaced citizens & $\begin{array}{l}\text { Citizens fall into the } \\
\text { Sustainable Development } \\
\text { Goal (SDG) framework. } \\
\text { Where social assistance is } \\
\text { provided, it should be on } \\
\text { the basis of equality. }\end{array}$ & $\begin{array}{l}\text { Policies to implement } \\
\text { social assistance may set a } \\
\text { target group or establish a } \\
\text { floor below which social } \\
\text { assistance will be provided. } \\
\text { In some cases, complaint } \\
\text { mechanisms are } \\
\text { established in law. }\end{array}$ & $\begin{array}{l}\text { Access to assistance is } \\
\text { often mediated by } \\
\text { geography; those in } \\
\text { inaccessible areas or out of } \\
\text { government control are } \\
\text { likely to be marginalised. } \\
\text { Displaced people typically } \\
\text { live in communities that } \\
\text { experience similar forms of } \\
\text { exclusion. 'Whole-of- } \\
\text { society approach' is called } \\
\text { for. }\end{array}$ \\
\hline Displaced citizens (IDPs) & $\begin{array}{l}\text { IDPs have rights to equal } \\
\text { access to forms of social } \\
\text { protection. }\end{array}$ & $\begin{array}{l}\text { Assistance may indirectly } \\
\text { exclude IDPs since } \\
\text { eligibility may involve } \\
\text { registration or residence } \\
\text { requirement. }\end{array}$ & $\begin{array}{l}\text { Widespread examples of } \\
\text { failure to protect and } \\
\text { provide for IDPs on basis } \\
\text { of citizenship. Concerns } \\
\text { around registration. }\end{array}$ \\
\hline $\begin{array}{l}\text { Refugees and other } \\
\text { displaced non-citizens }\end{array}$ & $\begin{array}{l}\text { Clear distinction between } \\
\text { refugees, who are to be } \\
\text { integrated into national } \\
\text { mechanisms, and others } \\
\text { who should be disregarded } \\
\text { and/or removed. }\end{array}$ & $\begin{array}{l}\text { Rare examples where } \\
\text { refugees are eligible for } \\
\text { social assistance require } \\
\text { registration and } \\
\text { recognition. Typically } \\
\text { involve partnership } \\
\text { between national } \\
\text { government and } \\
\text { UN/NGOs. }\end{array}$ & $\begin{array}{l}\text { Multiple examples where } \\
\text { refugees avoid official } \\
\text { systems due to fear or } \\
\text { engage in unexpected } \\
\text { ways. Basis and impact of } \\
\text { this is poorly understood. }\end{array}$ \\
\hline
\end{tabular}




\section{Gaps in the evidence}

Existing research is very strong on official policy approaches and analysis. This covers the complexity of connections between official national provision and external support, and the ways this is intended to reach different groups of displaced people. The clear gaps here are: (1) issues arising in implementing this policy and, (2) social assistance beyond official policy which displaced people make use of and strategise around. This involves the lived experience of displaced people, and the experience of frontline service providers in agencies providing social assistance. These gaps are grouped in four interrelated areas:

1. Patterns of inclusion and exclusion in policy provision. How does de jure or de facto exclusion operate for different groups of displaced people? How do residency or registration requirements affect uptake? How are processes of exclusion and inclusion viewed by frontline service providers?

2. What happens after exclusion? How do displaced people engage with official processes for registering complaints and how are their subsequent actions interpreted by those who examine complaints? What other options exist for displaced people excluded from protection? How do 'tactical' responses operate, involving protest, deception, or invisibility? How do social agencies or NGOs respond to such tactics?

3. What sources of social assistance exist in the local area beyond policy regimes? How do displaced people combine official and non-official social assistance, and how do they evaluate different sources? What forms of exclusion and inclusion exist in community organisations or faithbased provision? How do providers of assistance in those contexts view their roles?

4. What are the more distant sources of social assistance? To what extent do displaced people have access to pre-displacement locations or remittances from distant family members? How far are these sources reflected in official responses?

Figure 1: Gaps in evidence from perspectives of displaced people and frontline service providers

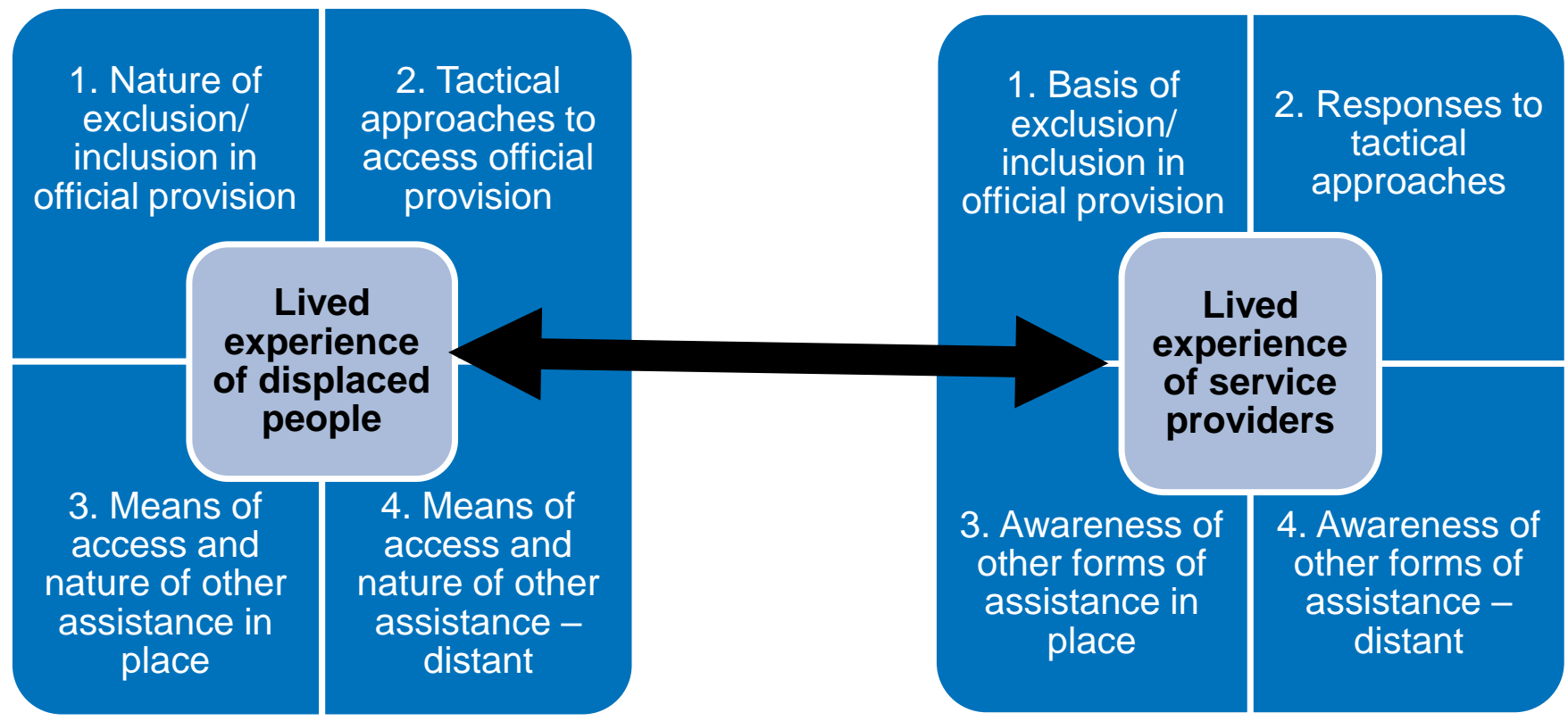

Source: Authors' Own 


\section{Directions for research}

In responding to these gaps, proposed research will focus on four areas:

- Lived experience of displaced people, focused around the four areas in Figure 1. This will include an assessment of the range of different sources of social assistance they can identify, with investigation of patterns of inclusion and exclusion from those sources, including any reasons for selfexclusion. This will be based on an intersectional understanding of individual access to power and subsequent responses to exclusion, including complaint, protest, or deception.

- Viewpoints of frontline implementing actors. Providers of protection may play important decisionmaking roles but interpret and respond to actions of displaced people in ways that facilitate or prevent their access to social protection. In addition to their perspectives on displacement, research will explore relationships between the whole spectrum of actors from national government and international organisations to faith provision, community groups and mutual aid.

- Whole-of-society approach. Policy to support displaced people now rarely considers displacement in isolation from the wider society. We will investigate the situation of those labelled as displaced and those not so labelled within the broader displacement-affected community.

- Self-determination. A critical assessment of self-reliance mechanisms is required to identify positive approaches and avoid elision with efforts to withdraw support. The tactics of displaced people will be investigated from a perspective that recognises their autonomy and considers a full portfolio of risk management mechanisms that they may put in place.

This thematic brief is a shortened version of two BASIC Research Working Papers. To explore this research theme in more detail please refer to:

Collyer, M.; te Lintelo, D.J.H.; Mutambasere, T. and Zaman, T. (2022) Moving Targets: Social Protection as a Link Between Humanitarianism, Development and Displacement, BASIC Research Working Paper 17, Brighton: Institute of Development Studies, DOI: 10.19088/BASIC.2022.017

Zaman, T.; Collyer, M.; Sabates-Wheeler, R. and Szyp, C. (2022) Beyond Rights-Based Social Protection for Forcibly Displaced People, BASIC Research Working Paper 6, Brighton: Institute of Development Studies, DOI: 10.19088/BASIC.2022.006

\section{Acknowledgements and Disclaimer}

This document was developed by the Better Assistance in Crises (BASIC) Research programme. BASIC is implemented by the Institute of Development Studies (IDS), the University of Sussex and the Centre for International Development and Training, funded by UKAid from the UK government. The views expressed in this document are entirely those of the authors and do not necessarily represent views or policies of the UK governments official policies.

(C) IDS copyright 2022. Copyright in the typographical arrangement and design rests with IDS.

This publication (excluding the logos) may be reproduced free of charge in any format or medium, provided that it is reproduced accurately and not used in a misleading context. The material must be acknowledged as IDS copyright with the title and source of the publication specified.

Published by IDS.

DOI: 10.19088/BASIC.2022.029 